\title{
REPORT
}

\section{"Migration AND ViOLENCE: Lessons FROM COLOMBIA FOR THE AMERICAS" A wORKSHOP OF THE Transatlantic Forum ON Migration and Integration AND the Refugee ResearCh NeTWORK (TFMI)}

\author{
JoRGE SALCEDo
}

\section{Introduction}

The conference, "Migration and Violence: Lessons from Colombia to the Americas" was held in Bogotá D.C., Colombia at the Pontificia Universidad Javeriana on June 29 2012. The main objective of the conference was to develop inter-disciplinary academic research in Central America and Mexico regarding the relationship between violence, particularly narco-violence, and migration. The setting in Bogotá D.C. was deliberate as the participants discussed how lessons learned from Colombia's experience with narco-induced migration could be leveraged for the benefit of Central America and Mexico. With the participation of experts on international migration, government representatives, academics, and civil society, the conference highlighted research results and relevant intervention experience concerning this problem in Colombia, El Salvador, Guatemala, and Mexico.

This article presents an analysis of the presentations given and the discussions held at the conference. It consists of four parts. The first section compares the similarities and differences regarding migration and violence in Colombia and El Salvador, Guatemala, and Mexico. The second section presents the major epistemological challenges emerging from research and models of intervention. The third section presents the implications of the epistemological challenges and their impact on public policy. The fourth section concludes with principal lessons from Colombia for research and intervention in the problem of violence and migration.

\section{Through a comparative lens: The relationship between migration and violence in Colombia, $\mathrm{El}$ Salvador, Guatemala, and Mexico \\ From the 1980s to present, Colombia and the region com- prised of El Salvador, Guatemala, and Mexico have experi- enced periods of armed internal conflict, gang-related aggression, and community violence which have produced forced migrations. ${ }^{1}$ While each country has encountered similar types of problems, each has experienced them at different times or at different levels of intensity. This has led each country to consider different forms of public policy to resolve the problem. ${ }^{2}$}

\section{Internal displacement generated by armed internal conflicts}

The armed internal conflicts between the leftist guerillas, the government, and other paramilitary structures were marked by gross violations of human rights and breaches of international humanitarian law that generated large flows of refugees and internally displaced persons (IDPs). In El Salvador, Guatemala and Nicaragua during the 1980s and mid-1990s about three million people were displaced and forced to find refuge in another part of the region or fled to the United States. ${ }^{3}$ Colombia has reported that from the late 1980s to present, there have been 4-5.5 IDPs and 400,000 refugees $^{4}$, the majority of whom have made their way to neighboring countries. ${ }^{5}$ In both cases, the humanitarian crises have had regional aspects characterized by 
restrictions pertaining to the protection of refugees in host countries.

In the Central American region, a set of peace agreements in the mid-1990s outlined a solution that worked to aid the return of a large portion of refugees and IDPs. However, in Colombia, the peace agreements signed in the 1990s did not obtain the commitment of all guerilla groups. As a result, the country still experiences violence and the return of internally displaced persons has been impeded, as the situation does not guarantee property restitution to the victims. Even though the country had implemented measures to ensure restitution in 1997, it has not been met with much success as guerilla groups continue to inhibit the implementation of these agreements. Likewise, extended efforts made in 2005 and 2011 by transitional justice frameworks recognized the rights of the IDPs in their condition as victims to truth, to justice, reparation, and to the guarantee that said events would not occur again. However, these measures have not been fully implemented and do not seem to identify the root of the problem. Unfortunately, sixty individuals ${ }^{6}$, who had taken it upon themselves to lead other victims in hope of exercising their rights, have been killed in recent years. ${ }^{7}$

Mexico emerged as a scene of political violence in the 1990s with the surge of Zapatista guerillas and paramilitary groups that were repressed by the government. Most of the violence occurred in southern Mexico and generated high levels of internal displacement of indigenous peoples in this area.

The political violence behind social and economic conflicts in Colombia, Guatemala, and El Salvador persisted despite the peace agreements signed in the two regions. Problems such as social exclusion, poverty, uneven distribution of land and wealth, and political corruption were not addressed by the aforementioned agreements and continued to neutralize any progress made.

\section{Forced Migration and Organized Crime}

In El Salvador, Guatemala, Mexico, and Colombia, violence and the frequent outbreak of organized crime have triggered forced migration and have victimized international migrants. In the first two countries mentioned, continuities exist from conflict to post-conflict periods as both countries have felt the impact of transnational crime ${ }^{8}$ on forced migration. In the last five years, following the peace accords, there has been a notable increase in migration. Organized crime in these four countries is composed not only by private armies engaged in illegal economic activity but also by the civil sector, military, police, businessmen, and politicians of different parties.

Meanwhile, violence in Mexico has been exacerbated to the extent that 60,000 causalities $^{9}$ have been reported in the last six years, with consequences for forced migration. On one hand, this has initiated an invisible refugee process made up of middle and upper class people fleeing to the United States and Canada, seeking protection. On the other hand, this has created internal displacement of those belonging to lower socio-economic classes without the monetary means to leave the country. These internally displaced persons (IDPs), estimated at 270,000, have been visible $^{10}$, as they have taken advantage of the shelters that have been erected by their municipalities.

Organized crime in Mexico has also victimized international migrants trying to reach the United States. In addition to being victims of human trafficking, migrants are vulnerable to attacks by Mexican cartels seeking to prevent the use of corridors that they have deemed most vital to the transit of illegal drugs, illicit money, and weapons. The network of corridors secures their transactions, allowing them to gain more economic stability and to place them in a position to seize more political power. Aside from taunting migrants who are attempt to use the corridors, the cartels monitor corridor gateways and demand money from the migrants' families who are waiting to help their relatives on the other side. Although this has reduced the amount of illegal immigration, it has increased the number of kidnappings of undocumented migrants.

In Guatemala for example, there is evidence that drug trafficking and money laundering have compromised the judicial system, which has contributed to the corruption of the banking system and entrepreneurship. The pharmaceutical industry, especially, has been targeted for its development of new synthetic drugs. In Mexico, there is the perception among a few sectors that the Federal government should have pursued the Gulf Cartel and the Zetas more than the Sinaloa cartel.

In relation to the visibility of these problems in public policy, the developments in Central America and Mexico arise mainly because authorities refuse to recognize the gravity of the situation. There are laws recognizing refugees from other countries but there are no laws that recognize the existence of internally displaced persons. However, the process to create a law for these victims is being discussed in Mexico. The repressive policy facing international migrants traveling through Mexico trying to reach the United States has been reduced, but it has been accompanied by a lack of protection against threats from organized crime. In Colombia, the institutional response to forced migration by violence has attracted a high level of expertise in the legal and institutional framework and has been able to produce tangible achievements not seen before in the case of victims' rights. Although state-sponsored responses have been low among the four countries, the Catholic Church 
and multiple NGOs have compensated for this by paying particular attention to the rights of migrants and displaced peoples.

In the case of Colombia, crime has intertwined with, and strengthened, the armed internal conflict under the guise of paramilitary counterinsurgency, making it one of the major drivers of forced displacement. In the background of organized crime in Colombia, there exists the dispute of over control of legal and illegal sources of economic resources in the territories such as mining, drug trafficking and public budgets. ${ }^{11}$

The fact that these groups have evolved by contracting integral control over territories through violent mediums reflects their desire to gain political power that includes control of everyday life while using methods that differ from guerrilla groups also present in Colombia. In these situations, these zones are managed in an authoritarian matter and have led to the displacement of people who do not follow the governance imposed within the violent and hegemonic areas. As far as human trafficking is concerned, Colombia is a country of origin, transit, and destination where the main victims are women and children. The women tend to be the heads of households and are, on average, between 18-24 years old. Those of African descent and the indigenous are among the most vulnerable.

In Central America and Mexico, there are no figures representing the magnitude and the characteristics of this new cycle of forced migrations due to violence in recent years. Meanwhile, Colombia has registered substantial improvements in systematizing information regarding displacement from state, church, and non-governmental sources, however problems still exist with underreporting.

\section{Forced Migration, Community Violence, and Young}

People

In both regions, the relationship between migration, organized crime, community violence and youth are closely related.

In Colombia, the most powerful criminal organizations control sectors of cities through its coordination with juvenile neighborhood gangs and local or micro local outreach. Correspondingly, the forced recruitment of young boys, girls, and adolescents is one of the main effects of internal displacement within the country.

Leftist guerillas recruit young people and minors, those who reside in rural and poor zones that have been neglected by the government, to their ranks. Similarly, new paramilitary groups recruit and utilize the youth community to increase their range of criminal activity in both rural and urban areas. The minors that have been linked to non-governmental armed groups are legally recognized as victims although they are victimizers as well. Lastly, IDPs fleeing from political violence in the countryside to cities are frequently victims of community violence in the zones where the heads of the gangs and dealers of hallucinogens are located.

In the case of Central America the large cartels have contributed to the scope and phenomena transnational crime where "maras" like "Salvatrucha" and "18" stand out and have established their presence in California in the United States. The spread of these gangs across international borders-Mexico, and of the Central American Triangle, particularly El Salvador-is in itself a product of the dynamics of migration, refuge, and deportations. In Guatemala, organized crime related to narcotics controls the gangs and uses repressive measures to legitimize itself among civil society, replacing the state's function as protector and regulator of the populace.

\section{Epistemological challenges for understanding the relationship between migration and violence.}

The experience of violence and migration in these four countries presents various valuable, but complex, epistemological challenges to understanding the links between violence and migration.

\section{Broadening the conceptual range of migration categories} and addressing current violence

Given the implications that conceptual categories for understanding migration have for the protection of migrants, overcoming the conceptual shortcomings of current categories used to describe migration induced by violence was one of the principal challenges identified by conference participants.

Although various adjectives, including political, economic, social, and cultural, are used to generate understandings of migration on micro and macro levels, care should be taken not to lose sight of the instances where these categories intersect or overlap. This points to the need to restructure the traditional categories of migration beyond the classification of refugee, IDPs, human trafficking, economic, natural disaster-related, and "mixed flows". If there is a situation of mixed flows wherein migrants do not fit into any pre-determined category, they face the possibility of being catalogued as an illegal immigrant in the country of destination where they will be refused rights and where there is no framework of protection made available to them.

Several solutions were discussed in response to the above mentioned problems, including: extending the existing categories, creating new categories that are more inclusive that cannot have universal validation claims but are commensurate to regional and local differences, and responsive 
instances of varying nature within their countries and other countries.

\section{An interdisciplinary view of migration and information systems}

The second biggest challenge discussed was the development of an interdisciplinary view on migration that takes into account different focal points of research such as wars, armed conflict, the economy, state mafias, transnational organized crime, drug trafficking, gangs, maras, poverty, inequality, and exclusion. In this sense, moving towards a more complete identification of the range and nature of novel research in this area, one that implements more robust methodologies, is important. Each country should define short, medium, and long-term research agendas that are key in the development of academic research groups and that strengthen the dialogue on the research and intervention, given that public policy does not always feed off of the developments made within research.

Among what has been prioritized in research, there are a few that stand out significantly: the return of migrants is a major part of different agendas concerning migration policies, including, for example, landholding. Another top priority is the research on the migration of women, children, afro-ethnic groups, and indigenous people due to the vulnerability that these groups face during migration and the lack of attention these cases receive. Collecting the stories of those who have been abused and victimized, especially stories from young gang members that have been a part of induced migrations is also a priority as they are seen as victims of domestic violence and have been robbed of economic opportunities, etc. Although there is a lack of academic work in the area, displacement that occurs along the borders has been given much attention. Similarly, it is necessary to advance the study of human trafficking focusing on public health, sexual and reproductive rights, beyond criminal acts. It is necessary to understand how violence can take many different forms and how these forms intersect to generate migrations; for example, the violence of powerful organized groups such as those who traffic drugs, their relations with official forces, and the blurred instances of community violence domestically and among the youth. The study of crime strategy and how armed groups control territories and achieve their objectives is also given high priority. Furthermore, the methods in which they combine silent and invisible forms of control using strategic information pertaining to the territories and the use of extreme demonstrations of violence and massacres. Additionally, it is of high priority to study the drug transportation routes within the United States that are normally conceived in Mexico.
Equally, it is important to improve the production and systematization of quantitative and qualitative data that allows the systematic study of migration and also allows public policy to monitor and address these studies. This is a great endeavor due to the different forms of forced migration that take place, especially when considering that they are not readily seen and often occur in secret. In Colombia, considerable advancements have been made to track forced displacement; however, information about destination points do not exist as Colombia lacks the secondary sources to keep a record of migrants once they have fled. Other occurrences that are associated with migration such as refuge, trafficking, and victimization suffer from systematic methodologies and are not as well documented. Meanwhile, systematic figures representing forced migrations due to current violence have been recorded in Central America and Mexico.

\section{Implications for Public Policy}

In regards to the violent actors that generate migration, the states should establish an area that is committed to the protection of rights and that manages the affects of such violence in the lives of the victims. Notwithstanding, the form in which the phenomena related to migration is defined and classified also determines the scope of national and international regimes in protecting the rights of the migrants. In other words, conceptual and methodological discussion to understand and classify forced migration is a political discussion in order to construct laws, institutions and establish priorities and applicable areas for public policies.

It is recognized that the tools to prevent new actors from impacting migration are lacking from public policy. Human rights laws provide the tools to violations within the state as international humanitarian law and transitional justice are meant to control non-state actors that want to become official state actors. However, tools are needed to control the actors today that have the dual ability of producing new orders without attempting to replace the state but can capture the state from "within" and to face the companies that are linked to grand violations of rights that have been regulated as of today.

The same issue arises with narco-traffickers, actors for which there are few tools or methods of engagement other than the criminal justice system. However, we find that the drug trafficker has certain capacity of governance, of territorial ordinance, and the ability to restructure economics, and so the question remains, how do you make peace with the drug traffickers after or beyond criminalization? In Colombia, there has been negotiation with the drug trafficking network disguised as political peace negotiations and, 
as a result, former narco-traffickers have become legitimate political actors.

Colombia is also illustrative of the consequences generated by forced displacement such punishable crime in regards to the attribution of penal and civil responsibilities. The traditional attribution of culpability to an individual that has generated forced displacement has been transcended by more systematic approaches to the consequences of crime. The Colombian approach to dealing with the loss of land by victims of crime is the best example of this trend. Colombia also faces the challenge of determining whether displacement took place due to political violence or other types of violence, differentiating the infractions of international humanitarian law within the framework of armed internal conflict, mass violations of human rights, generalized violence, and/or of internal strife and unrest. From the above, the classical distinctions within political violence and violence due to common organized crime do not appear to function adequately in all cases in order to account for the political nature of local actors like narcotraffickers, to the extent that it also groups diverse legal actors like officials and businessmen that seek to control political, economic, and social relations that are woven together in a territory.

In this sense, the Ley de Victimas y Restitución de Tierras or "The Law of Victims and Land Restitution" issued in 2011 in Colombia represents a setback in the recognition of rights of victims of displacement. Furthermore, the scope of protection for those who have been displaced due to fumigations, the victims of so-called emerging gangs, the victims who sough refuge abroad, and collective victims such as labor unions, as well as those who are a part of social movements and opposing parties. The economic activities in rural areas like mega-mining and the cultivation of agrocombustibles, among others, have raised questions as to how they can finance non-state armed groups that create new cycles of displacement.

It is important to advance a regional approach to migration and violence while taking into account the links between similar situations that exist within these countries in fields such as the regulation of illicit activities, the validity of peace, the development of democracy and the defence of human rights, regional integration and security, the state's presence through preventative policy, social and economic development, regulated economies and social institutions. If there exists globalized crime, the states should face the situation based on an integrated perspective through preventative policy.

Facing international migration, it is necessary to insist that states disassociate migration policy from national security because this convergence can affect the rights of the migrants that need protection.
It is also necessary that public policy on migration advance to adopt a management and indicator system that produces results permitting interested parties to monitor and control the situation through an interdisciplinary dialogue concerning rights and the economy.

\section{Conclusions: Lessons from Colombia for the Americas}

By and large, Central America and Mexico can learn from the case in Colombia. The adoption of a special institution tending to victims of complex situations of violence is linked to the process of peace negotiations as a way to resolve situations of grave violence.

The complexity of the violence in Colombia coalesces ideological armed internal conflict with armed disputes among apparatuses of power that combine illegal action with legal action in all aspects of their functioning. With respect to organized crime, it is another area where Central America and Mexico should further characterize the actual situations of humanitarian crisis, overcoming the narrowness of the categories defining migration and the analysis of traditional violence.

Considering that young people are frequently recruited by various armed organizations, they are their principal victims. The states should prioritize preventative policies beyond distinctly repressive policy. Likewise, they should provide specialized protection to women, children, and ethnic groups who are traditionally excluded, like those of indigenous and afro descent.

Similarly, the experience of multi-track analysis of migration and peace processes highlights the importance of considering different levels of incidence and negotiation. This involves not only states and international actors, but also social groups of distinct classes including flexible associations of social organizations, universities, churches and other authority figures. The aforementioned is key to face regional integration among the countries, their authorities, their social organizations, and citizens to agree on investigative agendas and intervention facilitating exchange and joint lessons about the complicated relations among migration and violence in the Americas.

They can also nourish themselves with the wealth of academic publications and research coming from Colombia concerning migration, violence, forced displacement, information tracking systems, and the adoption of public policy indicators tracking the effectiveness of rights. 


\section{Notes}

1. El Salvador and Guatemala, together with Honduras, comprise what is known as the "Northern Triangle" of Central America and share the same regional dynamic with Mexico

2. In this context, both regions at the same time or another, have been considered the most violent places on earth: Colombia in the 1980s and the 1990s; Mexico, in combination with the Northern Triangle in the 2000s till now.

3. Casasfranco Roldan and Maria Virginia, Las Migraciones y los Desplazamientos Forzados: Análisis Comparativo e Integral Desde un Enfoque de Derechos Humanos (San José de Costa Rica, 2001).

4. CODHES, "Desplazamiento Creciente y Crisis Humanitaria Invisibilizada," en Codhes Informa (Bogotá: CODHES, 2012).

5. At the forefront of forced displacement, women and children continue to be the principal victims due to their vulnerability and exposure to sexual violence within the community or familial. They suffer not only because of the armed internal conflict but also due to do everyday life in an unprotected state.

6. Caracol Radio, Junio 12 de 2012. http://www.caracol.com .co/noticias/judicial/mas-de-60-lideres-de-restitucion-de -tierras-han-sido-asesinados-en-siete-anos-defensoria-del -pueblo/20120612/nota/1704578.aspx.

7. In 2011, the displacement that took place in Colombia continued and increased to include 73 mass movements. Some were generated under counterinsurgency operations, for example, the operation commanded under Alfonso Cano and the FARC. Additionally, displacements occurred in the areas that had been given priority by the government and where intervention had been coordinated by military command. On the other hand, despite the major blows that have dealt to the guerillas, they are far from being defeated and the cost of the lives of official forces is high.

8. In both cases, organized crime has contributed to drug trafficking, arms trafficking, extortion, election fraud, manipulation of institutions, human trafficking, among others.

9. Miguel Wilchez Hinojosa, "Migration and Violence: Lessons from Colombia for the Americas," Bogotá, 2012.

10. Ibid.

11. Between 1980 and the mid-90s there were sharp disputes between large drug cartels that generated displacements, the scope of which is undeterminable due to the lack of information. These disputes surfaced again in the late-90s and early 2000s when the paramilitary group, United SelfDefense Forces of Colombia, had been formed. This contributed to another dispossession of a millions of hectares of productive land, the control of production and local institutions as well as another wave of forced migration. They reconfigured themselves following the government initiative to demobilize paramilitary groups in the first decade of the 2000s. Although paramilitary groups have been maintained to a certain extent, different criminal gangs have begun to emerge focusing on the consolidation of control over captured territories.

Jorge Salcedo teaches at Universidad del Rosario, Bogotá D.C., Colombia

TFMI is made possible through the generous sponsorship of the German Marshall Fund and Robert Bosch Stiftung. The Refugee Research Network is made possible through the generous support of York University, Canada. 